\title{
A Word on a Father
}

\section{Olha Sukhomlynska, Lesia Sukhomlynska}

\section{Introduction}

How does it feel like to be a descendant of a prominent person? Obviously, this is not only a great honor, a kind of a godsend, but also a big responsibility. It is extremely important to preserve the legacy of your own ancestors, carefully carrying on this precious treasure - because they would like it the most.

Being born into the family of a prominent teacher and innovator, the founder of humanistic pedagogy Vasyl Sukhomlynsky, and having spent her whole childhood in a world-famous Pavlysh school, Olha Sukhomlynsky never stood a chance to choose a profession unrelated to pedagogy.

She is a Member and Secretary of the Department of General Pedagogy and Philosophy of Education of the National Academy of Sciences of Ukraine, an expert in the theory and history of pedagogy, history of Ukrainian education and pedagogical thought, comparative pedagogy, education issues. As well as Professor Emeritus of Borys Grinchenko Kyiv University, Volodymyr Vynnychenko Central Ukrainian State Pedagogical University, Luhansk Taras Shevchenko National Pedagogical University, Beijing Normal University, Tianjin Academy of Pedagogical Sciences.

And, obviously, Olha Sukhomlynsky is an inspired researcher of her father's pedagogical heritage, a promoter of his work, a proponent of his ideas, an initiator of publishing his books (in particular, the most complete collection of Vasyl Sukhomlynsky's storiettes «I'll Tell You a Fairy Story... Philosophy for Children» was published this year under the compilation and editorship of Ms. Olha), as well as a living source of memories. It seems that a spiritual connection between these two nearest people, who have been on different sides of the border for forty-eight years, separating our imperfect world from another - the unknown one - still exists.

... They were even born on almost the same day, with only a few dozen years apart. In addition, both - almost on the eve of Teacher's Day. This is, certainly, a coincidence (Teacher's Day was only established as a holiday in 1965). It is quite symbolic though. On September 28, Vasyl Sukhomlynsky would have celebrated 98, and on September 29 Olha celebrated her 70th anniversary. She participated in the opening of the 
exhibition "Vasyl Sukhomlynsky», which was held at the Pedagogical Museum of Ukraine at Volodymyrska Street the week before. Attending this event without communicating with Olha Sukhomlynska was impossible (especially in the anticipation of Teacher's Day) - this family plays an extremely important role in the history of Ukrainian pedagogy. And simply for the sake of getting a better feel for that era. That is what «Education of Ukraine» did in the cozy hall of the pedagogical library of the Kyiv City Teacher's House.

- Ms. Olha, during the opening of the exhibition, the chairman of the Vasyl Sukhomlynsky All-Ukrainian Association, Oleksandra Savchenko, expressed her hope that you will write a book of memoirs about $V$ asyl Sukhomlynsky, regarding bim not as an educator, but as a person. Have you already thought about writing such a book?

- I wrote a book called «The Pavlysh School. A Look through the Years» a few years ago. It refers to the period of father's directorship in Pavlysh, and of course, it contains specific elements of his personal life. In addition, I have touched upon these topics in many articles when discussing various aspects of his work. For example, how father made up fairy tales or was a head of the Pavlysh School. After all, it is impossible to separate his personal life from what actually made up a large part of his educational work.

\section{A portrait in letters}

- Still, the idea of writing a book about him as a father seems quite rightbecause a lot of has been written about Vasyl Sukhomlynsky as a teacher and innovator, thinker and writer. And nobody will tell better about Sukhomlynsky as a person than you. You are the only carrier of these memories. And it is extremely interesting to know, what type of person he was in his everyday life? For example, even this aspect: there is quite often such a trite situation that talented teachers do not have enough time and effort for their own children. Were you somehow neglected by your prominent father as a child?

- Of course, my father was a very busy person. Both he and mom worked at school. Actually, we lived at school, and had «school-family education». He was rarely at home, but he did not lose sight of me and my brother's records. In addition, we were principal's children - from a very young age we were introduced to the school life, took part in all afterschool activities, in amateur talent groups. When summer holidays came, parents did not go somewhere to relax; they took us to Moscow, Leningrad, Kyiv, to exhibitions, museums and theaters - father thought that he was obliged to introduce all of it to us, and in the village, of course, there were no such cultural centers where we could get acquainted with such epitomes of cultural life. So, I did not feel the lack of attention from my parents. 
Regarding him as a personality ... It seems to me that he told a lot about himself as a person in his works. Hardly anyone can write about him better than himself. He died at the age of 52, quite young, and his personal life was rather inseparable from school, from his activities as a principal, a teacher. Reading and re-reading his works today, I see that they characterize him exactly the same as he was in everyday life.

If we talk about the ideas of writing a book about my father ... The archive preserves a great epistolary heritage, which I am going to compile and publish. He received many letters and as a rule corresponded to all of them: mothers, parents, students, high schoolers. He had many correspondents, some of whom he kept in touch with for a long time. There are letters to me, to my brother, to my mother - even in two languages (my mother was Russian, and at the beginning of their relationships, he wrote letters to her and then translated them, so that she would learn the language faster). Arranging this epistolary legacy is a task that is topical for me personally, because I know many of his correspondents, as well as how life turned out for them, and what the purpose of the letters was. I know that if I do not do this, it is unlikely that anyone will be able to cope with it, even when they take on this task. Because to someone who is out of the picture, it will take a lot of effort and time to purely search and find out who these people were, where they worked. And I can do it only by knowing their names. My mother and I, at one time, addressed these correspondents and asked to send the letters that father wrote to them. A lot of them have already been collected; all letters are now in folders, sorted by authors. Writers, authors, and even priests wrote to him. For the ideas of spirituality and goodness which father advocated can't leave anybody indifferent. In addition, he did correspondence with those kids who were in the juvenile detention center. There are letters from the parents of those children who couldn't «fit in» with the class and get on with the teacher. By the way, there are much less such letters from teachers than from parents. He replied to everyone. So, looking through the prism of the «book about father» - I think it should be in such a format: letters, replies and my comments on them. Such an edition will greatly reveal the portrait of Vasyl Sukhomlynsky.

\section{Uncensored}

- Is there anything left in Sukhomlynsky's creative heritage - besides this correspondence - which remains, shall we say, obscure to us?

- Of course, because Vasyl Oleksandrovych wrote and rewrote a lot. But here's a little different question. Within the period of independence in Ukraine, the attention was devoted first of all to his fairy tales, literary and 
publicistic heritage; this part of his oeuvre was published the most. But in order to even republish his works, a lot of work must first be done, namely you need to review the manuscript, editorials and notes as they were then added to the text, and finally the final version. After all, what Sukhomlynsky wrote and what was later published are slightly different works. So what was the publishing houses' policy back to the Soviet era? The text had to contain the decision of the latest plenum of the party, the words of another leader or the Secretary General in this regard. His most famous book, «To Children I Give My Heart, A New Reading,» was recently republished. While working on this publication, I dug through archives - an authentic manuscript and those reviews in which he was bombarded with accusations of writing about Baba Yaga, and not mentioning anything about Lenin in a hut, as well as about the leading role of the Communist Party. I have published an authentic text outlining the changes made by the reviewers and the department in question. This is a tremendous work - work with archives, research. And it should be carried out with each father's book. Moreover, «To Children I Give My Heart» is a lifetime publication, Sukhomlynsky himself regulated the number and size of these editorial changes, decided what could be thrown away and what should be left. However, he had many program works that he could not publish. These are «How to Raise a True Character,» and «One Hundred Pieces of Advice for Teachers,» «Methods of Educational Work with a Teaching Staff,» and «Conversation with a young principal» - the latest works of the mature period, which were published after father's death. What publishers did with those manuscripts - that is another story. For example, in the book «How to Raise a True Character» some sections are rearranged, the text is shorten, whole paragraphs are thrown away. In 1989 I published this book in Moscow as it was first in the manuscript, according to the original sources. Then the authentic text came out in China, but we had no such reprint here in Ukraine. Therefore, much work needs to be done to eliminate the ideological touches that were added in accordance with the censors' wishes. By the way, all the former socialist countries are doing this by re-publishing books which were published during the so-called socialism times.

- And when were Sukhomlynsky's works last republished?

- I have just received a three-volume edition from Moscow: «To Children I Give My Heart», «Birth of a citizen» and «Letters to a son.» On the one hand, I'm glad that these books have come out, on the other - I was not even told about that. The publisher, who issued Sukhomlynsky's fairy tales, happened to see them in Moscow and brought them to me. Otherwise I wouldn't find out about them. 
Trends and Prospects of the Education System and Educators' Professional ...

- That means that the Russians published your father's books without your permission? Is this possible?

- Of course, everything is possible today. They seized our Donbas without our permission, let alone the books...

\section{An abstract humanist}

- Ms. Olha, how «Soviet» was your father? It seems to me that as an educator he was not quite "Soviet» in the conventional sense of the word, was he?

- He was severely criticized in the second half of the 1960s; he was accused of being an abstract humanist, preacher, that words «love to a child» sounds more like priest's words. Why was he called an abstract humanist? Because he said that all children should be loved. And Soviet pedagogy urged to love only Soviet children. And the capitalists' - how dare you? Capitalists are our enemies. Now it sounds wild and funny, but back then it was said seriously. There was a great deal of discussion around these issues, I gathered all the material and compiled it in the book «Pedagogical Apocrypha. Essays on Sukhomlynsky.«

... On the other hand, he believed in those communist ideals. Considering the fact that a large part of his activity was carried out in the 60's - especially after Khrushchev's report, after the words that the current generation will live under communism - I think he was a romantic idealist.

- In your opinion, how relevant are Sukhomlynsky's works now, in the middle of a digital technologies boom and the diversity of pedagogical schools and systems? Is there a future for his books and ideas? Can they stand the test of time in a world that has long been dominated by other ideas, rhythms, and to some extent - other values?

You surely understand that from me personally you will receive a clear answer. I will even quote Austrian researcher of Sukhomlynsky's heritage Alan Kokkeril, because I do share his views. He is a representative of Western civilization, born in England, raised in Australia. He is now very active in promoting Sukhomlynsky's ideas among the English-speaking society, especially teachers and parents. I asked him, «Why?» He replied that the capitalist world emasculates the importance of a person; it believes that things and life are more important than a person, that there is a lack communication between parents and children, who are moving away from each other, that there is not a «humanization» of the society, but its «objectification» and fetishization. And Sukhomlynsky in all his works called, first of all, to see a person in each child, to see the good in them in any situation, to rely on the positive. And to admit that every child is a unique value. Even if something doesn't work out, there are objective reasons. And the second thing this Australian researcher points out (and I tend to agree 
with it as well) Sukhomlynsky approaches the child holistically. This is called a holistic approach. The main thing is to love a child, to respect them, to understand them.... Now everyone says that there should be no grades in elementary school - these are, so to speak, the latest pedagogical trends. But Sukhomlynsky wrote about it in the 60's! He emphasized that you mustn't in any case give kids bad grades, instead you should support and praise them in every possible way, even for the slightest success. Because a kid wants that praise in elementary school. This is one of the so-called pedagogical constants, which will remain as long as a notion of school exists.

\section{Crystalization through the years}

- When we came to the exbibition dedicated to your father, we expected to see a large crowd of people. But there were quite a few. Do you feel that nowadays less attention is given to Vasyl Sukhomlynsky's personality - in particular, from the representatives of the teaching community?

- Of course, attention is getting less. However, there is no canonical or obligatory manner. This is something I even really like. Now in our country, as anywhere else in the world, we have access to any system and teacher; and anyone (whether a teacher or a parent) can choose the system and ideas that either fit their inner world (if it's an active-minded person) or, let's just say, the ones which "are trending.» When, for example, everyone goes «to Montessori» - that's fine - why not? But when they say that Sukhomlynsky is already outdated, sorry, Montessori lived in the early 20th century. The validity and value of these ideas - both Montessori and Sukhomlynsky - is strengthened by the fact that they «crystallize» over time. There will be no mass interest, after all - it is not necessary. Because it is specific to authoritarian societies. Besides, I am not a fan of crowded events. The exhibition was attended by people who do share his ideas. And I think that the amount of visitors was quite high despite the fact that so many years have passed.

- It is a well-known fact that Sukhomlynsky's books have been published in 53 languages with a total circulation of almost 15 million copies. He is known, studied and respected in many countries of the world - Europe, Asia, Australia, the United States. But Vasyl Sukhomlynsky's works and his personality per se are of particular popularity (and much greater one than in Ukraine) in China. As for me, this is a mystery - why have Chinese educators chosen our fellow countryman Sukhomlynsky as a pedagogical standard? Not Slavs or even Europeans. We have different traditions, culture, and mentality. There seems to be no common grounds. Do you have any explanation for this?

- There may be several explanations. There are actually some common grounds. This is a certain similarity of ideologies, and attitude to 
nature, to its beauty - this contemplation, which is inherent in the Eastern society, attention to details, Sukhomlynsky's traditional approach to parents and kids - such purely family values are very common to the Chinese, and of course, love to a child. In my opinion, all of these reasons together have created such attention of the Chinese colleagues to the works of Vasyl Sukhomlynsky. In some pedagogical universities, a graduate is not even awarded a diploma unless he or she passes the «One Hundred Pieces of Advice for Teachers» exam. And they have quite a creative attitude to it. In particular, students perform the following task: After reading this book, write twenty pieces of advice to the teacher - on a personal note. There is, in my opinion, another reason why the Chinese have chosen Sukhomlynsky: they understand everything he writes about. He did not write in a scientific, academic or scholastic language, but in a simple and human one. His writings are about a teacher, an ordinary village boy, some examples from life - this simplicity appeals to them.

\section{Nobody is forgotten}

- Ms. Olha, you are not only your father's daughter, but also an independent selfsufficient scholar with your own biography and great creative endeavours. What do you do today, except for dealing with Vasyl Sukhomlynsky's creative heritage? What are you research interests?

- Organizing my father's heritage is my hobby, I do it with pleasure. In general, I research the history of the Ukrainian school and pedagogy, first of all, 1920-1930's. It was a time of innovation and experiments (especially the 20's), new trends and influences, time when Ukrainian pedagogy absorbed new Western tendencies; there were many new and unknown things in the school development: pedology, reflexology, complex approach, psychotechnics, scientific management. This is extremely interesting, and I have quite a lot of publications on these topics devoted to this period.

In addition, I lead some research groups, we have published a solid two-volume piece «Ukrainian Pedagogy in Personalities», which describes and covers prominent educators starting from Kievan Rus, National Renaissance and ending with our educators who have recently passed away. I deal with the educational problems of moral and ethical, civic education.

Also, I am the head of the All-Ukrainian Association of Pedagogical Historians, and every year we hold all-Ukrainian historical-pedagogical events in different cities, including readings, conferences, round tables on topical issues of the history of Ukrainian pedagogy and school. For example, this November, an event called «The University as a Center for European Culture» was held at the Lviv National University jointly with the 
Department of Pedagogy there. Prior to this event, there were many conferences on various topics. Which exactly? For example, «Innovative Educational Institutions in Ukraine«- we published the book of the same title under my scientific editorship. I wrote a big section there - about the Ukrainian Gymnasium of Taras Shevchenko, which was located on the territory of the Pokrovsky Monastery (the room is not preserved). It was a purely national educational institution, headed by Volodymyr Durdukivsky, one of the first Ukrainian principals, executed in 1937. He had family ties with Sergei Yefremov, and was first arrested during the Union for the Liberation of Ukraine process. However, half a school was put in prison at that time. Durdukivsky, Hermaise, Manzhos who also died - names that cannot be forgotten. Let's take Boris Manzhos, who was a supporter of the occupational direction in pedagogy. I was the only researcher who has written about him. I was collecting archival data piece by piece, and there was even a moment when I wanted to leave it all. And then I thought, if I don't write, no one else will ever mention him. As if the person did not exist at all. But he really did. All of them did. And they should be remembered.

\section{References}

Suhomlinskaya O.V. (2016) A word on a father. Education of Ukraine, 12-13. 